\title{
Molecular characterization of Toxoplasma gondii isolates from free-range chickens reveals new genotypes in Goiânia, Goiás, Brazil
}

\author{
Caracterização molecular de Toxoplasma gondii isolados de galinhas caipiras \\ revela novos genótipos em Goiânia, Goiás, Brasil \\ Hanstter Hallison Alves Rezende1* (1); Jaqueline Ataíde Silva Lima da Igreja²; Antônio Roberto Gomes-Júnior²; \\ Jade de Oliveira Melo²; João Luís Garcia3; Felippe Danyel Cardoso Martins³; Heloísa Ribeiro Storchilo²; \\ Taynara Cristina Gomes²; Marina Clare Vinaud²; Ana Maria de Castro²
'Laboratório de Bioquímica Clínica e Líquidos Corporais, Unidade Acadêmica de Ciências da Saúde, Universidade Federal de Jataí - UFJ, Jataí, GO, Brasil
${ }^{2}$ Laboratório de Estudos da Relação Parasito-Hospedeiro, Instituto de Patologia Tropical e Saúde Pública, Universidade Federal de Goiás - UFG, Goiânia, GO, Brasil
${ }^{3}$ Laboratório de Protozoologia Veterinária, Universidade Estadual de Londrina - UEL, Londrina, PR, Brasil

\begin{abstract}
How to cite: Rezende HHA, Igreja JASLD, Gomes-Júnior AR, Melo JDO, Garcia JL, Martins FDC, et al. Molecular characterization of Toxoplasma gondii isolates from free-range chickens reveals new genotypes in Goiânia, Goiás, Brazil. Braz J Vet Parasitol 2021; 30(2): e000321. https://doi.org/10.1590/S1984-29612021029
\end{abstract}

\begin{abstract}
The aim of this study was to evaluate the genotypic characteristics of Toxoplasma gondii isolated from free-range chickens in the metropolitan area of Goiânia, Goiás, in Brazil's central-west region. The seroprevalence rate was found to be $96 \%$, according to an indirect hemagglutination assay. Brain and heart samples were processed by peptic digestion for a mice bioassay. The tissues were homogenized and the resulting samples were subjected to polymerase chain reaction (PCR), which revealed that $64 \%$ of them contained the parasite's DNA. The mice bioassay revealed 15 isolates, 8 of them tachyzoites isolates from the peritoneal lavage and 7 from brain cysts. T. gondii genotypes were determined through PCR-RFLP, using the following markers: SAG1, SAG2, SAG3, BTUB, GRA6, c22-8, c29-2, L358, PK1, alt. SAG2, Apico and CS3. Three genotypes were identified, inclued ToxoDB \#65, and the other two are not yet described in the literature. Hence, we conclude that the isolates obtained from the metropolitan area of Goiânia showed relatively low genetic diversity.
\end{abstract}

Keywords: Toxoplasma gondii, molecular characterization, free-range chickens, bioassay, PCR-RFLP, genetic diversity.

\begin{abstract}
Resumo
O objetivo deste estudo foi avaliar as características genotípicas de Toxoplasma gondii isolados de galinhas caipiras da Região Metropolitana de Goiânia, Goiás, Região Centro Oeste do Brasil. A soroprevalência foi de $96 \%$ dos animais, determinada por hemaglutinação indireta. As amostras de cérebro e coração foram processadas através da digestão péptica para o bioensaio em camundongos. Os tecidos foram homogeneizados, e as amostras resultantes foram analisadas por reação em cadeia da polimerase (PCR), que possibilitou a detecção do DNA do parasito em $64 \%$ deles. Por meio do bioensaio em camundongos, foi possível detectar 15 isolados, 8 deles apresentando taquizoítos na lavagem peritoneal e 7 apresentando cistos cerebrais. A determinação dos genótipos de $T$. gondii foi realizada por PCR-RFLP com os seguintes marcadores: SAG1, SAG2, SAG3, BTUB, GRA6, c22-8, c29-2, L358, PK1, alt. SAG2, Apico e CS3. Foi possível definir 3 genótipos, incluindo o ToxoDB \# 65 e dois deles ainda não foram descritos na literatura. Portanto, conclui-se que os isolados obtidos na região metropolitana de Goiânia apresentaram diversidade genética relativamente baixa.
\end{abstract}

Palavras-chave: Toxoplasma gondii, caracterização molecular, galinhas caipiras, bioensaio, PCR-RFLP, diversidade genética.

Received: January 11, 2021. Accepted: March 12, 2021.

*Corresponding author: Hanstter Hallison Alves Rezende. E-mail: hanstter@gmail.com 


\section{Introduction}

Free-range chickens (Gallus gallus) are considered indicators of environmental contamination by Toxoplasma gondii because they feed directly from the soil, which exposes them to oocysts (Dubey et al., 2003a; Zhu et al., 2008; Millar et al., 2012). Humans infected with T. gondii are usually asymptomatic. However, the infection may present clinically in congenitally infected children and in immunocompromised individuals (Dubey \& Jones, 2008; Murat et al., 2013). The seroprevalence of toxoplasmosis among pregnant women in the municipality of Goiânia, state of Goiás, Brazil, was reported to be $51.85 \%$ (Avelar et al., 2015). It was also demonstrated that $13.6 \%$ of stray cats in the same region were shedding $T$. gondii oocysts in their feces. Both these rates are considered high when compared to those in other regions of the world (Rezende, 2015).

In Brazil, the seropositivity rate of anti-T. gondii antibodies in free-range chickens varies from $22.4 .3 \%$ to 88.4\% (Dubey et al., 2020). Prevalence in the eastern part of the state of Goiás was found to be $16.5 \%$ and in the metropolitan area of Goiânia it was $50 \%$ in chicken sold in the market (Alves, 2007), while free-range chicken sold on farms showed 38\% prevalence (Silveira, 2013). These data indicate the high seroprevalence of toxoplasmosis in the state of Goiás among free-range chicken, which is directly attributable to environmental contamination, and this, in turn, leads to high seroprevalence rates in humans and other hosts (Dubey et al., 2003b; Millar et al., 2012).

Molecular characterization studies of $T$. gondii isolates in North America and Europe showed low variability, enabling them to be grouped into three clonal types (I, II, III) (Howe \& Sibley, 1995). Type I isolates were classified as highly lethal in mice, regardless of the initial inoculum, while types II and III isolates showed lower lethality, since this characteristic was directly attributed to the initial inoculum (Sibley et al., 2009). T. gondii isolates from different regions in South American countries have shown high genetic diversity, revealed by studies of genetic polymorphisms of DNA fragments generated by restriction enzymes and polymerase chain reaction (polymerase chain reaction-restriction fragment length polymorphism - PCR-RFLP). The parasite has been shown to be highly genetically diversified and should therefore not be considered clonal, especially since recombinant and atypical strains have been detected (Brandão et al., 2006; Lehmann et al., 2006; Pena et al., 2008).

A genetic analysis of isolates from Brazil led to the identification of typically Brazilian clonal lineages, which were classified as Brl, Brll, Brlll and BrlV. These are different from the classic types according to their virulence. Therefore the Brazilian genotypes were classified as: Brl virulent, Brlll non-virulent, while genotypes Brll and BrIV present intermediate virulence. The level of virulence was classified based on a mouse mortality model, as virulent (100\% mortality), intermediate ( $>30 \%$ mortality) and non-virulent ( $<30 \%$ mortality) (Pena et al., 2008).

Knowledge about the phenotypic and genotypic characteristics of $T$. gondii isolates is necessary in order to understand the complex host-parasite relationship (Saraf et al., 2017). However, pathogenicity depends on several factors, including host susceptibility, virulence of the isolate and time of infection (Dubremetz \& Lebrun, 2012).

There are no studies that demonstrate the $T$. gondii genotypes circulating among different hosts in Goiás. Considering the role of free-range chickens as environmental bioindicators, the purpose of this study was the molecular characterization of $T$. gondii isolates from these animals, thus shedding light on the level of toxoplasmosis in the metropolitan area of Goiânia, Goiás, Brazil.

\section{Material and Methods}

This study was approved by the Ethics Committee on Animal Use of the Federal University of Goiás, Brazil, (CEUA/UFG), under Protocol no. 024/2016.

\section{Characterization of the study area}

The state of Goiás is located in the central west region of Brazil, and its capital is Goiânia. The metropolitan area of Goiânia (MAG) comprises 18 satellite towns and rural areas with highly developed farming activities, especially cattle, poultry, fruit and vegetable farming. The predominant climate in Goiás is the seasonal tropical, dry winter, with temperature ranging from 22 to $23^{\circ} \mathrm{C}$ (Casaroli et al., 2018). 


\section{Free-range chickens}

Fifty free-range chickens were randomly selected from six farms within the metropolitan area of Goiânia, Goiás, Brazil. The 50 chickens came from the following municipalities: 10 from Abadia de Goiás; 17 from Aparecida de Goiânia; 5 from Goiânia; 10 from Hidrolândia, and 8 from Trindade (Figure 1).

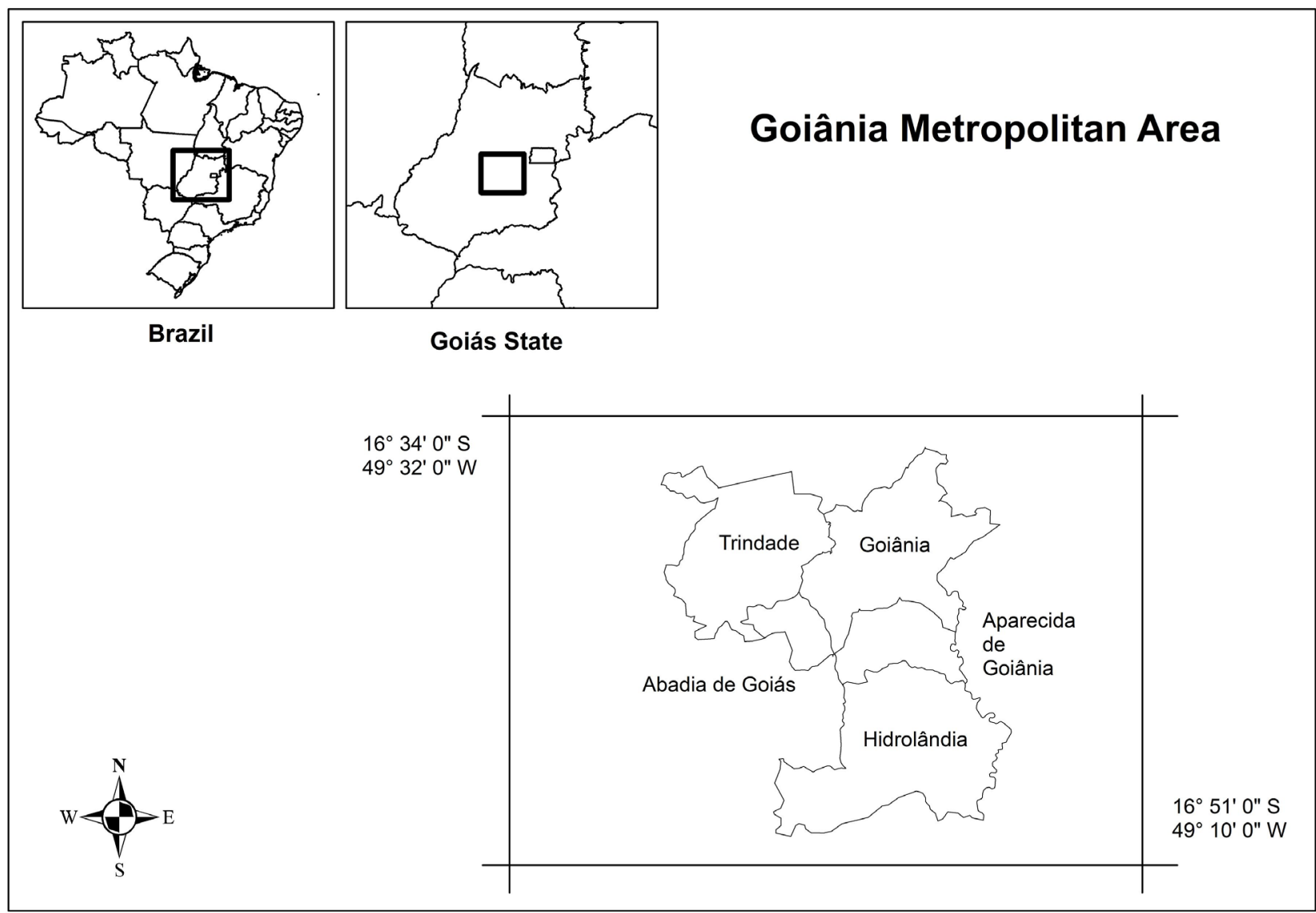

Figure 1. Metropolitan area of Goiânia, capital of the state of Goiás, in Brazil's central western region.

The chickens were euthanized on the farms, exsanguinated, and a blood sample was collected without anticoagulant. The animals were then decapitated, and their brains and hearts were removed. The samples were placed in a sterile container at $4^{\circ} \mathrm{C}$ and taken to the Laboratory of Host-Parasite Relationship Studies at the Federal University of Goiás (LAERPH/UFG). The blood samples were centrifuged at 2,500 $\mathrm{g}$ for $15 \mathrm{~min}$ in order to separate the serum, which was stored at $-20^{\circ} \mathrm{C}$ until it underwent serological analysis.

\section{Serological analysis}

The serum samples were subjected to an indirect hemagglutination assay (IHA) using a Toxotest Wiener Lab ${ }^{\circledR}$ commercial kit. The samples were considered reactive when they presented a titer of $\geq 32$. All the reactions were carried out with a positive and negative control, of the commercial kit itself, and the reactive samples were diluted down to a titer of $\geq 1024$.

\section{Bioassay in mice}

The brains and hearts of seropositives chickens' in the IHA were weighed and then macerated together in a domestic food processor, totalizing about 50 grams of tissue, with $250 \mathrm{ml}$ of $0.85 \% \mathrm{NaCl}$, followed by peptic digestion with acid pepsin (Dubey, 1998). The resulting homogenate was treated with 1,000 $\mathrm{U}$ of penicillin and $200 \mathrm{mg}$ of streptomycin. After this, $1 \mathrm{ml}$ of the homogenate was injected intraperitoneally into groups of three 30-day-old Swiss mice (male or female). The rest of the homogenate was stored at $-80 \mathrm{C}$ for subsequent DNA extraction. 
The inoculated mice were monitored daily for a period of up to 60 days to identify the acute signs of toxoplasmosis. Symptomatic animals were euthanized, a peritoneal lavage was performed with $0.85 \% \mathrm{NaCl}$, and the tachyzoites were examined under an optical microscope. Positive samples from the peritoneal lavage and other organs of these mice were stored at $-80^{\circ} \mathrm{C}$ for subsequent DNA extraction. Part of the peritoneal lavage was inoculated in other mice to maintain the isolate.

After the 60 day period, the asymptomatic animals were euthanized and blood samples were collected by intracardiac puncture. The serum samples were examined under indirect immunofluorescence (IFI) (Camargo, 1964), using anti-mouse IgG conjugate (Sigma-Aldrich $($ ). Mice were considered positive when they presented titers of $>40$. Their lungs and brains were removed and a fragment of these tissues was analyzed under a light microscope to look for T. gondii cysts (Dubey \& Beattie, 1988). Samples of tissue that tested positive were macerated in sterile $0.85 \% \mathrm{NaCl}$ and also stored at $-80 \mathrm{C}$ for later DNA extraction.

\section{DNA extraction and Toxoplasma gondii detection by PCR}

DNA was extracted directly from the chicken tissue homogenate, peritoneal lavages from mice with virulent isolates and from macerated brain/lungs from mice with non-virulent isolates. Tachyzoites from Toxoplasma gondii $\mathrm{RH}$ strain were used as positive control and blood from non-inoculated / non-infected mice as negative control. All the extractions were performed using commercial BIOPUR ${ }^{\circledR}$ Kit Mini Spin Plus.

DNA samples extracted from chicken tissue homogenate were subjected to PCR amplification of $T$. gondii B1 gene using the following primers: Toxo-B5 (5'-TGA AGA GAG GAA ACA GGT GGT CG-3'), Toxo-B6 (5'-CCG CCT CCT TCG TCC GTC GTA-3') (Santos et al., 1993). A final volume of $25 \mu$ l was used, containing $17.3 \mu$ l of sterilized Milli-Q water, $1.0 \mu \mathrm{L}$ of $\mathrm{MgCl}_{2}, 2.5 \mu \mathrm{l}$ of Buffer 10X (Invitrogen $\left.{ }^{\circledR}\right), 0.2 \mu \mathrm{l}$ of Taq DNA Polymerase (Invitrogen $\left.{ }^{\circledR}\right), 0.5 \mathrm{mM}$ of each deoxynucleotide (dATP/ dTTP/ dGTP/ dCTP, Sigma ${ }^{\circledR}$ ), 50 pmol of each reaction initiator (Invitrogen ${ }^{\circledR}$ ), and $2 \mu$ l of extracted DNA.

The amplification process consisted of an initial denaturation at $94^{\circ} \mathrm{C}(5 \mathrm{~min}), 35$ denaturation cycles at $94^{\circ} \mathrm{C}$ (1 $\mathrm{min})$, annealing at $62^{\circ} \mathrm{C}(1 \mathrm{~min})$ and an extension at $72^{\circ} \mathrm{C}(1 \mathrm{~min})$, followed by a final extension at $72^{\circ} \mathrm{C}$ for $10 \mathrm{~min}$.

\section{Molecular analysis}

The PCR-RFLP procedure was performed on DNA samples from the isolates, using 12 different markers: SAG1, 5'-3' SAG2, alt. SAG2, SAG3, BTUB, GRA6, C22-8, C29-2, L358, APICO, and CS3 (Pena et al., 2008; Su et al., 2010).

Samples of clonal archetypes (Type I-GT1, Type II-PTG and Type III-CTG) and reference samples (TgCgCa1, MAS, TgCatBr5, TgCatBr64, and TgRsCr1) were used as control. The primers, reaction conditions and the respective restriction enzymes were the same as those described in the literature (Pena et al., 2008; Su et al., 2010).

The results of agarose gel electrophoresis were analyzed and the genotypes were classified using the ToxoDB platform (ToxoDB, 2018). The identified genotypes were combined with the control genotypes, using Splits Tree software version 5 (Huson \& Bryant, 2006).

\section{Results}

\section{Serology and detection of Toxoplasma gondii DNA in free-range chicken tissues}

Of the total of 50 analyzed free-range chickens, 96\% (48/50) were positive for anti-T. gondii IgG antibodies. Antibody titers varied from 32 to $\geq 1024$. Forty-two percent (21/50) of the samples presented a titer equal to 64 . T. gondii DNA was detected by PCR in 64\% (32/50) of the samples of tissue homogenates, a summary of results are presented in Table 1.

\section{Toxoplasma gondii isolated from tissues of free-range chickens}

A total of 48 mice bioassays were performed from the positive chicken tissues, resulting in 15 isolates (31.3\%). Of these, 8 presented tachyzoites from mice with acute toxoplasmosis symptoms, while 7 isolates were obtained from tissue cysts removed from asymptomatic mice. 
Table 1. Results of serology by HAl, PCR of Gene B1 of tissue homogenate and result of bioassay of 50 free-range chickens in the metropolitan area of Goiânia, state of Goiás, in Brazil's central western region.

\begin{tabular}{|c|c|c|c|c|c|c|}
\hline Chicken & Locality & HAl title & $\begin{array}{c}\text { PCR the } \\
\text { homogenate } \\
\text { tissue }\end{array}$ & $\begin{array}{c}\text { Mice positive in } \\
\text { bioassay }\end{array}$ & $\begin{array}{l}\text { Parasitic } \\
\text { form }\end{array}$ & Nomenclature \\
\hline 01 & Hidrolândia & 32 & + & - & - & - \\
\hline 02 & Hidrolândia & 128 & + & $1 / 3$ & Cyst & TgCkBrGO01 \\
\hline 03 & Hidrolândia & 256 & + & - & - & - \\
\hline 04 & Hidrolândia & 128 & + & - & - & - \\
\hline 05 & Hidrolândia & $>1024$ & + & $3 / 3$ & Tachyzoite & TgCkBrGO02 \\
\hline 06 & Hidrolândia & 128 & + & - & - & - \\
\hline 07 & Hidrolândia & $>1024$ & - & - & - & - \\
\hline 08 & Hidrolândia & 256 & - & - & - & - \\
\hline 09 & Hidrolândia & 128 & + & - & - & - \\
\hline 10 & Hidrolândia & 128 & + & $1 / 3$ & Cyst & $\operatorname{TgCkBrGO03}$ \\
\hline 11 & Aparecida de Goiânia & 128 & + & - & - & - \\
\hline 12 & Aparecida de Goiânia & 128 & + & $3 / 3$ & Tachyzoite & TgCkBrGO04 \\
\hline 13 & Aparecida de Goiânia & 64 & + & $3 / 3$ & Tachyzoite & TgCkBrGO05 \\
\hline 14 & Aparecida de Goiânia & 256 & + & $3 / 3$ & Tachyzoite & TgCkBrGO06 \\
\hline 15 & Aparecida de Goiânia & 64 & + & $2 / 3$ & Cyst & $\operatorname{TgCkBrGO07}$ \\
\hline 16 & Aparecida de Goiânia & $N R^{*}$ & - & - & - & - \\
\hline 17 & Aparecida de Goiânia & 64 & + & $1 / 3$ & Tachyzoite & $\operatorname{TgCkBrGO08}$ \\
\hline 18 & Aparecida de Goiânia & 256 & + & - & - & - \\
\hline 19 & Aparecida de Goiânia & 64 & + & $2 / 3$ & Tachyzoite & TgCkBrGO09 \\
\hline 20 & Aparecida de Goiânia & 64 & + & $3 / 3$ & Tachyzoite & $\operatorname{TgCkBrGO10}$ \\
\hline 21 & Aparecida de Goiânia & $N R^{*}$ & - & - & - & - \\
\hline 22 & Aparecida de Goiânia & 64 & - & - & - & - \\
\hline 23 & Aparecida de Goiânia & 64 & + & - & - & - \\
\hline 24 & Aparecida de Goiânia & 64 & + & - & - & - \\
\hline 25 & Aparecida de Goiânia & 64 & + & $1 / 3$ & Cyst & $\operatorname{TgCkBrGO11}$ \\
\hline 26 & Aparecida de Goiânia & 64 & - & - & - & - \\
\hline 27 & Aparecida de Goiânia & 64 & - & - & - & - \\
\hline 28 & Abadia de Goiás & 32 & + & - & - & - \\
\hline 29 & Abadia de Goiás & 128 & - & - & - & - \\
\hline 30 & Abadia de Goiás & 64 & - & - & - & - \\
\hline 31 & Abadia de Goiás & 32 & - & - & - & - \\
\hline 32 & Abadia de Goiás & 64 & - & - & - & - \\
\hline 33 & Abadia de Goiás & 64 & - & - & - & - \\
\hline 34 & Abadia de Goiás & 32 & + & - & - & - \\
\hline 35 & Abadia de Goiás & 64 & + & - & - & - \\
\hline
\end{tabular}

*Non reagent. 
Table 1. Continued...

\begin{tabular}{|c|c|c|c|c|c|c|}
\hline Chicken & Locality & HAI title & $\begin{array}{c}\text { PCR the } \\
\text { homogenate } \\
\text { tissue }\end{array}$ & $\begin{array}{l}\text { Mice positive in } \\
\text { bioassay }\end{array}$ & $\begin{array}{l}\text { Parasitic } \\
\text { form }\end{array}$ & Nomenclature \\
\hline 36 & Abadia de Goiás & 64 & + & - & - & - \\
\hline 37 & Abadia de Goiás & 64 & + & - & - & - \\
\hline 38 & Trindade & $>1024$ & + & - & - & - \\
\hline 39 & Trindade & 64 & + & $1 / 3$ & Cyst & TgCkBrG012 \\
\hline 40 & Trindade & 256 & + & $3 / 3$ & Tachyzoite & TgCkBrG013 \\
\hline 41 & Trindade & 256 & - & - & - & - \\
\hline 42 & Trindade & 64 & - & - & - & - \\
\hline 43 & Trindade & 128 & + & - & - & - \\
\hline 44 & Trindade & 128 & - & - & - & - \\
\hline 45 & Trindade & 64 & + & $1 / 3$ & Cyst & $\operatorname{TgCkBrG014}$ \\
\hline 46 & Goiânia & 128 & + & $1 / 3$ & Cyst & TgCkBrG015 \\
\hline 47 & Goiânia & 128 & - & - & - & - \\
\hline 48 & Goiânia & 64 & - & - & - & - \\
\hline 49 & Goiânia & 32 & + & - & - & - \\
\hline 50 & Goiânia & 128 & - & - & - & - \\
\hline
\end{tabular}

*Non reagent.

\section{Genotypic analysis of Toxoplasma gondii isolates}

The genotypic characterization of the 15 isolates from the bioassays is described in Table 2. Only 9 isolates presented amplification of all the markers. Seven isolates pertained to genotype \#65 from ToxoDB, and two isolates had not been previously described in the literature.

The phylogenetic tree computed using Splits Tree software shows the diversity of the isolates and the distance between the clonal archetypes (Figure 2).

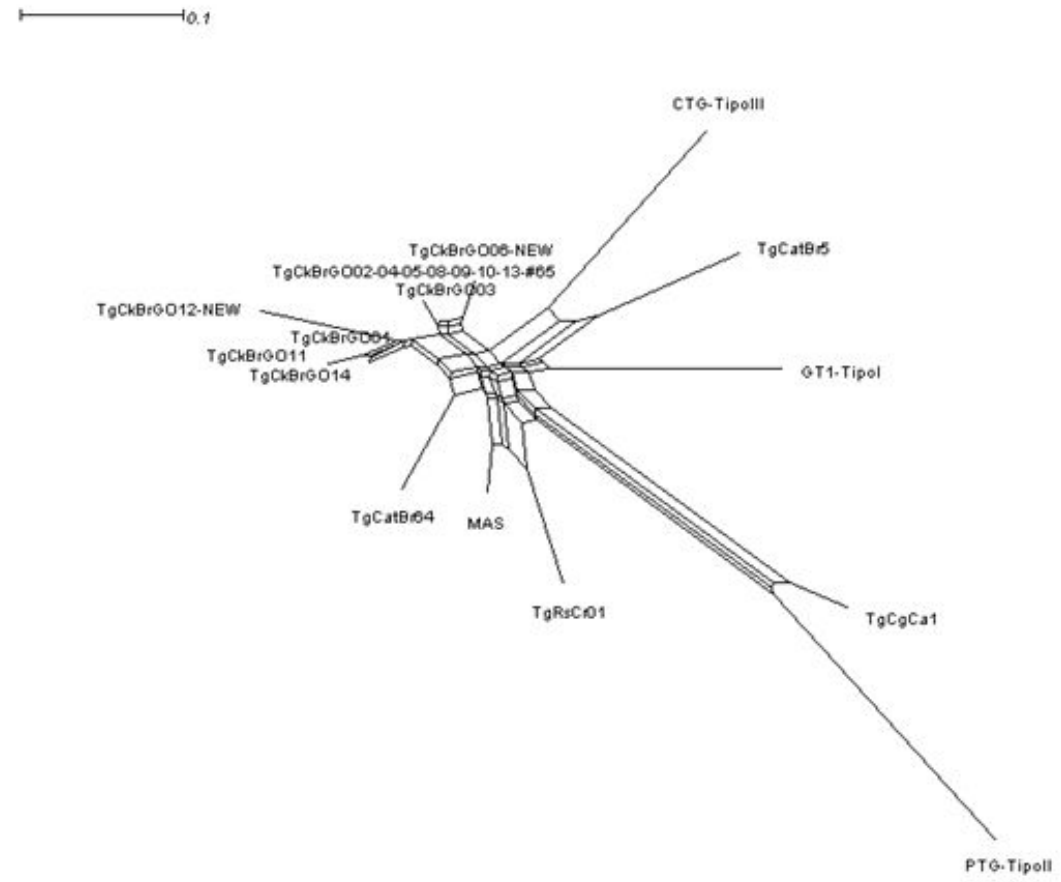

Figure 2. Phylogenetic tree of Toxoplasma gondii isolates from naturally infected free-range chickens in the metropolitan area of Goiânia, state of Goiás, in Brazil's central western region. The reference genotypes included here were GT1 = type I, PTG = type II, and CTG = type III, and the atypical genotypes were MAS, TgCatBr5, TgCatBr64, TgCgCa1 and TgRsCr1. 


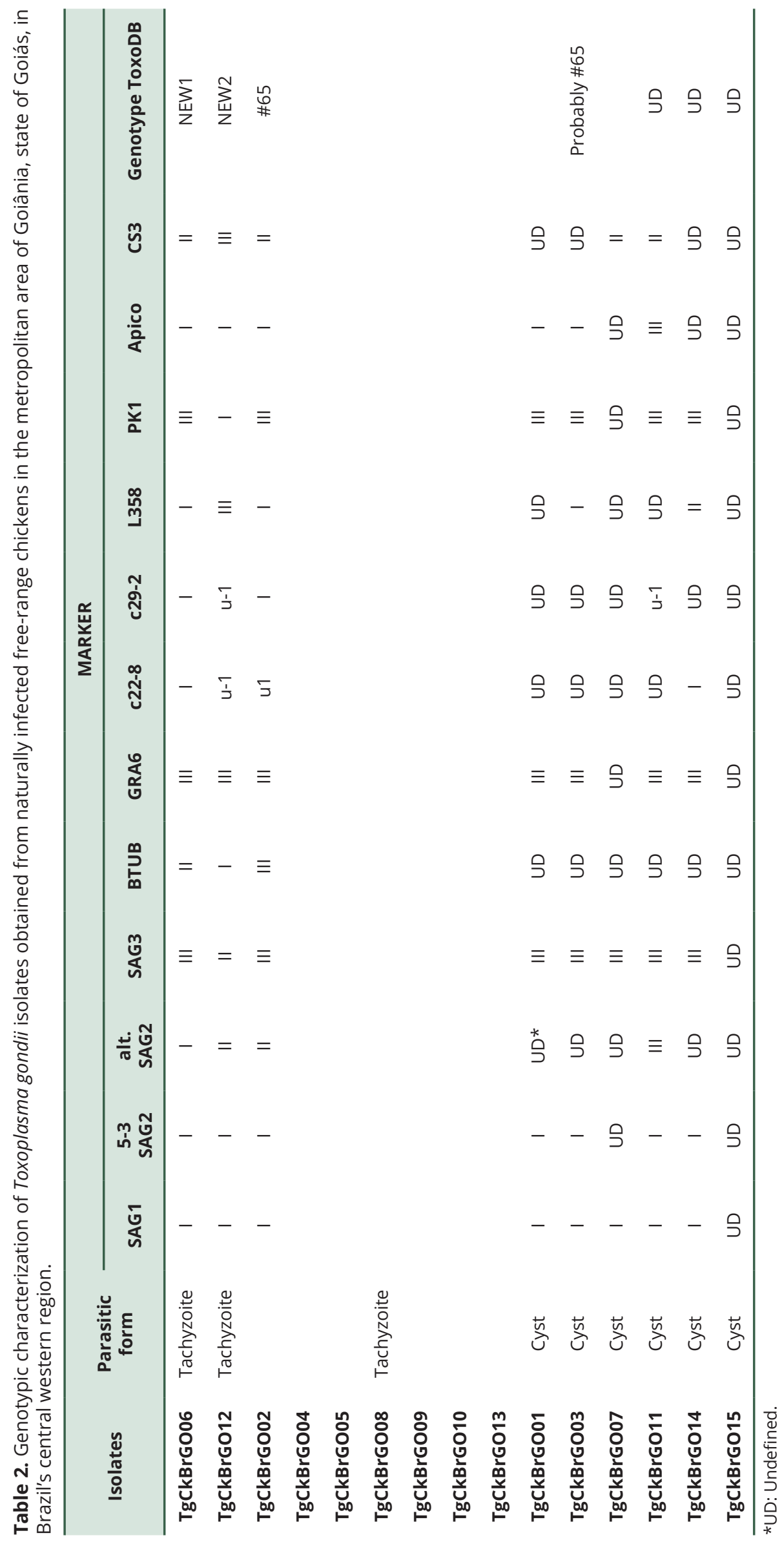




\section{Discussion}

This study evaluated the genotypic characteristics of $T$. gondii isolates identified in the state of Goiás. The frequency of seropositive free-range chickens (96\%) observed in our study is higher than that described in earlier studies in Goiás, which reported prevalence rates ranging from $16.5 \%$ to $50 \%$ in free-range chickens (Alves, 2007; Silveira, 2013, Silveira et al., 2014). Mato Grosso do Sul, another state in Brazil's central western region, has a reported prevalence rate of $67.5 \%$ (Silveira, 2009). In the north of Brazil, a prevalence rate of $66 \%$ was reported in the state of Rondônia (Dubey et al., 2006), while $88.4 \%$ was reported on the island of Fernando de Noronha, in northeastern Brazil (Magalhães et al., 2016). Other reported prevalence rates in Brazil were 71.3\% in the southeastern state of Minas Gerais, and 74.4\% in the southern state of Rio Grande do Sul (Camillo et al., 2015). The differences in reported prevalence rates may be attributed to the level of environmental contamination by $T$. gondii oocysts, as well as the different techniques used in serological surveys, the farming systems, the influence of climate, etc. (Millar et al., 2012). Another important factor that deserves to be mentioned, albeit outside the scope of this study, was the visual confirmation of the close coexistence of cats and chickens on the farms of this study. This may explain the high seroprevalence found in the analyzed chickens. However, it should be noted that cats roam over a distance of up to five kilometers (Dubey \& Beattie, 1988; Millar et al., 2012).

In this study, T. gondii DNA was amplified in 64\% (32/50) of the samples of chicken tissues. The detection of DNA in these tissues is an important finding, even when the viability of the parasite is not confirmed in cysts (Gutierrez et al., 2010), because T. gondii may be transmitted by handling carcasses, or eating raw or undercooked chicken meat (Alvarado-Esquivel et al., 2009). Transmission may also occur through the consumption of undercooked chicken viscera, which is a very common habit in many regions of Brazil, including in the state of Goiás (Millar et al., 2012; Fernandes et al., 2016).

In this study, 31.3\% of the bioassays were positive for T. gondii (15 isolates from 48 bioassays). Other studies have reported T. gondii positivity rates of $28.05 \%$ to $100 \%$ in isolates from chicken tissues (Dubey et al., 2007; Trevisani et al., 2017). The variations in these rates can probably be attributed to the tested tissues, given that some may show higher rates than others. In this study we used a heart and brain mixture, and it has been reported that the inoculation of a homogenate from a single organ into a single mouse increases the chance of isolation (Dubey et al., 2007; Beltrame et al., 2012).

Nine of the 15 isolates were successfully genotyped, and none of them were found to belong to the classic clonal types I, II or III, according to other Brazilian studies. The Brazilian isolates had a high reticulated phylogenetic relationship, suggesting that the genetic recombination plays an important role in the diversification of this species in Brazil (Pena et al., 2008). Meantime, our results illustrate the low genetic variability of the isolates under study, which was confirmed by their distance on the phylogenetic tree (Figure 2).In addition, to this day, there is no evidence of the other two genotypes in the literature or database, therefore, authors consider these as novel genotypes. Seven genotypes were identified as ToxoDB \#65 (Table 2). Genotype \#65 has been identified in chickens in Rio de Janeiro (Dubey et al., 2003a) and Espirito Santo (Pena et al., 2013), pigeons in Paraná (Barros et al., 2014), pigs in Pernambuco (Samico-Fernandes et al., 2015) and cats in São Paulo (Pena et al., 2006). In humans, this genotype was identified in São Paulo, where it was reported in chorioretinitis and in toxoplasmic encephalitis (Ferreira et al., 2011). These data demonstrate the wide circulation and geographic distribution of this genotype in several different hosts.

\section{Conclusions}

The high frequency of seropositive animals detected in this study should be examined carefully by public health authorities, since it is indicative of a highly contaminated environment. The $T$. gondii isolates obtained in this study in the metropolitan area of Goiânia showed low genetic variability and diversity, leading to the detection of two isolates not heretofore described in the literature. This study demonstrated the risk of $T$. gondii transmission to humans through the ingestion of free-range chicken, which is part of the region's traditional cuisine. Based on the results, preventive measures should be adopted, such as preventing cats from having access to chicken farms, environmental sanitation measures, introducing chicken-based food, and guidance on proper cooking and good feeding practices.

\section{References}

Alvarado-Esquivel C, Torres-Castorena A, Liesenfeld O, García-López CR, Estrada-Martínez S, Sifuentes-Alvarez A, et al. Seroepidemiology of Toxoplasma gondii infection in pregnant women in rural Durango, Mexico. J Parasitol 2009; 95(2): 271-274. http://dx.doi.org/10.1645/GE-1829.1. PMid:18922040. 
Alves EC. Toxoplasma gondii: soroprevalência, isolamento e virulência de cepas obtidas de galinhas caipiras (Gallus gallus) comercializadas em feiras livres do município de Goiânia [dissertação]. Goiânia: Universidade Federal de Goiás; 2007.

Avelar JB, Rezende HHA, Storchilo HR, Candido RRL, Amaral WN, Avelino MM, et al. Reativação da toxoplasmose durante o oitavo mês de gestação. Rev Renome 2015; 4(1): 57-69.

Barros LD, Taroda A, Zulpo DL, Cunha IAL, Sammi AS, Cardim ST, et al. Genetic characterization of Toxop/asma gondii isolates from eared doves (Zenaida auriculata) in Brazil. Rev Bras Parasitol Vet 2014; 23(4): 443-448. http://dx.doi.org/10.1590/s198429612014073. PMid:25517521.

Beltrame MA, Pena HF, Ton NC, Lino AJ, Gennari SM, Dubey JP, et al. Seroprevalence and isolation of Toxoplasma gondii from freerange chickens from Espírito Santo state, southeastern Brazil. Vet Parasito/ 2012; 188(3-4): 225-230. http://dx.doi.org/10.1016/j. vetpar.2012.03.053. PMid:22541793.

Brandão GP, Ferreira AM, Melo NM, Vitor RWA. Characterization of Toxoplasma gondii from domestic animals from Minas Gerais, Brazil. Parasite 2006; 13(2): 143-149. http://dx.doi.org/10.1051/parasite/2006132143. PMid:16800123.

Camargo ME. Improved technique of indirect immunofluorescence for serological diagnosis of toxoplasmosis. Rev Inst Med Trop São Paulo 1964; 6: 117-118. PMid:14177810.

Camillo G, Cadore GC, Ferreira MST, Braünig P, Maciel JF, Pivoto FL, et al. Toxoplasma gondii and Neospora caninum antibodies in backyard chickens in Rio Grande do Sul, Brazil. Rev Bras Cienc Avic 2015; 17(2): 263-265. http://dx.doi.org/10.1590/1516$635 \times 1702263-265$.

Casaroli D, Rodrigues TR, Martins APB, Evangelista AWP, Alves J Jr. Padrões de chuva e de evapotranspiração em Goiânia, GO. Rev Bras Meteorol 2018; 33(2): 247-256. http://dx.doi.org/10.1590/0102-7786332004.

Dubey JP, Beattie CP. Toxoplasmosis of animals and man. Boca Raton: CRC Press; 1988.

Dubey JP. Refinement of pepsin digestion method for isolation of Toxoplasma gondii from infected tissues. Vet Parasitol 1998; 74(1): 75-77. http://dx.doi.org/10.1016/S0304-4017(97)00135-0. PMid:9493311.

Dubey JP, Graham DH, da Silva DS, Lehmann T, Bahia-Oliveira LM. Toxoplasma gondii isolates of free-range chickens from Rio de Janeiro, Brazil: mouse mortality, genotype, and oocyst shedding by cats. J Parasitol 2003a; 89(4): 851-853. http://dx.doi. org/10.1645/GE-60R. PMid:14533703.

Dubey JP, Navarro IT, Graham DH, Dahl E, Freire RL, Prudencio LB, et al. Characterization of Toxoplasma gondii isolates from free range chickens from Paraná, Brazil. Vet Parasitol 2003b; 117(3): 229-234. http://dx.doi.org/10.1016/j.vetpar.2003.09.003. PMid:14630431.

Dubey JP, Gennari SM, Labruna MB, Camargo LM, Vianna MC, Marcet PL, et al. Characterization of Toxoplasma gondii isolates in free-range chickens from Amazon, Brazil. J Parasitol 2006; 92(1): 36-40. http://dx.doi.org/10.1645/GE-655R.1. PMid:16629312.

Dubey JP, Sundar N, Gennari SM, Minervino AH, Farias NA, Ruas JL, et al. Biologic and genetic comparison of Toxoplasma gondii isolates in free-range chickens from the northern Pará state and the southern state Rio Grande do Sul, Brazil revealed highly diverse and distinct parasite populations. Vet Parasitol 2007; 143(2): 182-188. http://dx.doi.org/10.1016/j.vetpar.2006.08.024. PMid:16982151.

Dubey JP, Jones JL. Toxoplasma gondii infection in humans and animals in the United States. Int J Parasitol 2008; 38(11): 12571278. http://dx.doi.org/10.1016/j.ijpara.2008.03.007. PMid:18508057.

Dubey JP, Pena HFJ, Cerqueira-Cézar CK, Murata FHA, Kwok OCH, Yang YR, et al. Epidemiologic significance of Toxoplasma gondii infections in chickens (Gallus domesticus): the past decade. Parasitology 2020; 147(12): 1263-1289. http://dx.doi.org/10.1017/ S0031182020001134. PMid:32660653.

Dubremetz JF, Lebrun M. Virulence factors of Toxoplasma gondii. Microbes Infect 2012; 14(15): 1403-1410. http://dx.doi. org/10.1016/j.micinf.2012.09.005. PMid:23006855.

Fernandes MFTS, Cavalcanti EFTSF, Silva JG, Mota AR, Souza OL No, Santos AS, et al. Occurrence of anti-Toxoplasma gondii antibodies and parasite DNA in backyard chicken breeding in Northeast, Brazil. Braz J Vet Parasitol 2016; 25(1): 105-108. http:// dx.doi.org/10.1590/S1984-29612016012. PMid:27007250.

Ferreira IM, Vidal JE, de Mattos CC, de Mattos LC, Qu D, Su C, et al. Toxoplasma gondii isolates: multilocus RFLP-PCR genotyping from human patients in Sao Paulo State, Brazil identified distinct genotypes. Exp Parasitol 2011; 129(2): 190-195. http://dx.doi. org/10.1016/j.exppara.2011.06.002. PMid:21741380.

Gutierrez J, O'Donovan J, Williams E, Proctor A, Brady C, Marques PX, et al. Detection and quantification of Toxoplasma gondii in ovine maternal and foetal tissues from experimentally infected pregnant ewes using real-time PCR. Vet Parasitol 2010; 172(1-2): 8-15. http://dx.doi.org/10.1016/j.vetpar.2010.04.035. PMid:20510517. 
Howe DK, Sibley LD. Toxoplasma gondii comprises three clonal lineages: correlation of parasite genotype with human disease. J Infect Dis 1995; 172(6): 1561-1566. http://dx.doi.org/10.1093/infdis/172.6.1561. PMid:7594717.

Huson DH, Bryant D. Application of phylogenetic networks in evolutionary studies. Mol Biol Evol 2006; 23(2): 254-267. http:// dx.doi.org/10.1093/molbev/msj030. PMid:16221896.

Lehmann T, Marcet PL, Graham DH, Dahl ER, Dubey JP. Globalization and the population structure of Toxoplasma gondii. Proc Natl Acad Sci USA 2006; 103(30): 11423-11428. http://dx.doi.org/10.1073/pnas.0601438103. PMid:16849431.

Magalhães FJ, da Silva JG, Ribeiro-Andrade M, Pinheiro JW, Aparecido Mota R. High prevalence of toxoplasmosis in freerange chicken of the Fernando de Noronha Archipelago, Brazil. Acta Trop 2016; 159: 58-61. http://dx.doi.org/10.1016/j. actatropica.2016.03.034. PMid:27032879.

Millar PR, Alves FXM, Teixeira VQ, Vicente RT, Menezes EM, Sobreiro LG, et al. Occurrence of infection with Toxoplasma gondii and factors associated with transmission in broiler chickens and laying hens in different raising systems. Pesq Vet Bras 2012; 32(3): 231-236. http://dx.doi.org/10.1590/S0100-736X2012000300009.

Murat J-B, Fricker Hidalgo H, Brenier-Pinchart M-P, Pelloux H. Human toxoplasmosis: which biological diagnostic tests are best suited to which clinical situations? Expert Rev Anti Infect Ther 2013; 11(9): 943-956. http://dx.doi.org/10.1586/14787210.2013.82 5441. PMid:24053275.

Pena HFJ, Gennari SM, Dubey JP, Su C. Population structure and mouse-virulence of Toxoplasma gondii in Brazil. Int J Parasitol 2008; 38(5): 561-569. http://dx.doi.org/10.1016/j.jpara.2007.09.004. PMid:17963770.

Pena HFJ, Soares RM, Amaku M, Dubey JP, Gennari SM. Toxoplasma gondii infection in cats from São Paulo state, Brazil: Seroprevalence, oocyst shedding, isolation in mice, and biologic and molecular characterization. Res Vet Sci 2006; 81(1): 58-67. http://dx.doi.org/10.1016/j.rvsc.2005.09.007. PMid:16289158.

Pena HFJ, Vitaliano SN, Beltrame MAV, Pereira FEL, Gennari SM, Soares RM. PCR-RFLP genotyping of Toxoplasma gondii from chickens from Espírito Santo state, Southeast region, Brazil: new genotypes and a new SAG3 marker allele. Vet Parasito/ 2013; 192(1-3): 111-117. http://dx.doi.org/10.1016/j.vetpar.2012.10.004. PMid:23116899.

Rezende HHA. Prevalência de parasitos intestinais em gatos errantes em Goiânia - Goiás: ênfase no diagnóstico de Toxoplasma gondii e avaliação da acurácia de técnicas parasitológicas [dissertação]. Goiânia: Universidade Federal de Goiás; 2015.

Samico-Fernandes EF, de Melo RP, de Cássia Peixoto Kim P, de Almeida JC, de Barros LD, Garcia JL, et al. First report of genotype \#65 of Toxoplasma gondii in pigs. Parasitol Res 2015; 114(10): 3927-3930. http://dx.doi.org/10.1007/s00436-015-4664-z. PMid:26268568.

Santos FR, Pena SDJ, Epplen JT. Genetic and population study of a Y-linked tetranucleotide repeat DNA polymorphism with a simple non-isotopic technique. Hum Genet 1993; 90(6): 655-656. http://dx.doi.org/10.1007/BF00202486. PMid:8444472.

Saraf P, Shwab EK, Dubey JP, Su C. On the determination of Toxoplasma gondii virulence in mice. Exp Parasitol 2017; 174: 25-30. http://dx.doi.org/10.1016/j.exppara.2017.01.009. PMid:28153801.

Sibley LD, Khan A, Ajioka JW, Rosenthal BM. Genetic diversity of Toxoplasma gondii in animals and humans. Philos Trans $R$ Soc Lond B Bio/ Sci 2009; 364(1530): 2749-2761. http://dx.doi.org/10.1098/rstb.2009.0087. PMid:19687043.

Silveira LH. Caracterização biológica e genotípica de isolados de Toxoplasma gondii obtidos de galinhas de criação livre do Pantanal do Mato Grosso do Sul [tese]. São Paulo: Universidade de São Paulo; 2009. http://dx.doi.org/10.11606/T.10.2009.tde-08122009-154206.

Silveira OJ No, Taveira RZ, Amaral AG, Oliveira BC, Nascimento EPB. Avaliação da ocorrência de Toxoplasma gondii em galinhas de postura caipiras criadas na região do oeste goiano. Encicl Biosf 2014; 10(18): 510-516.

Silveira OJ No. Perfil soroepidemiológico e detecção molecular de Toxoplasma gondii em Gallus gallus e Columba livia da região metropolitana de Goiânia, Goiás [dissertação]. Goiânia: Universidade Federal de Goiás; 2013.

Su C, Shwab EK, Zhou P, Zhu XQ, Dubey JP. Moving towards an integrated approach to molecular detection and identification of Toxoplasma gondii. Parasitology 2010; 137(1): 1-11. http://dx.doi.org/10.1017/S0031182009991065. PMid:19765337.

Trevisani N, Barros LD, Vieira-Neto A, Sartor AA, Souza AP, Garcia JL, et al. Genotyping of Toxoplasma gondii isolates from naturally infected Gallus domesticus in Santa Catarina state, Brazil. Arq Bras Med Vet Zootec 2017; 69(1): 139-145. http://dx.doi. org/10.1590/1678-4162-8594.

ToxoDB. Toxoplasma Informatics Resources. [online]. 2018 [Cited 2018 jan 15]. Available from: https://toxodb.org/toxo/app.

Zhu J, Yin J, Xiao Y, Jiang N, Ankarlev J, Lindh J, et al. A sero-epidemiological survey of Toxoplasma gondii infection in free-range and caged chickens in northeast China. Vet Parasitol 2008; 158(4): 360-363. http://dx.doi.org/10.1016/j.vetpar.2008.09.024. PMid:19022581. 